COPIM • Books Contain Multitudes: Exploring Experimental Publishing (2022 update)

\title{
Part 2: A Typology of Experimental Books
}

Janneke Adema ${ }^{1}$, Tobias Steiner ${ }^{1}$, Simon Bowie ${ }^{1}$, Marcell Mars

${ }^{1}$ Centre for Postdigital Cultures, Coventry University

Published on: Apr 26, 2022

DOI: 10.21428/785a6451.cd58a48e

License: Creative Commons Attribution 4.0 International License (CC-BY 4.0). 
This typology provides an overview of different types of experimental academic books. It outlines the experimental forms, formats, and relationalities authors and publishers are experimenting with as part of their long-form research and publishing activities. As explained in the previous part of this report, this typology does not aim to be a fixed classification, it is meant to function as a resource for scholars, publishers, and the larger research community that can be updated and can be added to. Our aim with this typology is to provide more information about the manifold forms and shapes scholarly books currently come in beyond the standard codex format, to inspire others to experiment with alternative models, materialities, and methods for book creation and distribution. Through this typology-and especially through the examples listed herewe also want to promote and highlight some of the exceptionally high quality and diverse work that is taking place in the realm of (post)digital scholarship, as well as the possibilities for experimentation digital tools and technologies offer for the research and publishing process.

This typology is a work in progress and will be updated with new examples as part of the different versions this report will be released in. What you are reading now is the second version of this typology (see here for version 1.0). This typology will next be developed into an online resource or Compendium for and maintained by the scholarly community (for more information about the further development of this Compendium see part 3 of this report). As explained previously, most of the examples listed here are in English and published in the US, the UK, and Europe. We hope to add more examples of languages other than English and from a wider array of regions in future versions. If anyone reading this has experimental books they would like to see included, please add them in the comments on the PubPub version, or contact this report's authors and we will see if we can add them to a future version.

The examples of books listed underneath have been chosen because we feel they illustrate well the different types of experimental books identified in this report. However, many examples listed underneath straddle several categories-i.e., the categories are not exclusive. Finally, although we have categorised the books listed underneath as, for instance, a versioned book or a hybrid book, this doesn't necessarily mean the authors or contributors to the books would similarly place them within these categories or describe them as such. As the examples listed underneath are often representations of complex, multi-compound, and collaborative projects, instead of providing our own descriptions of the books, we have chosen to source the 
descriptions provided underneath from project websites and publishers websites, among others.

\section{Computational Books}

Books that include or incorporate code as part of their critical content or that execute or run code as part of their knowledge production or publication process. 1

\section{Cox, Geoff and Soon, Winnie (2021) Aesthetic Programming: A Handbook of Software Studies [online] Open Humanites Press. http://www.openhumanitiespress.org/books/titles/aesthetic-programming/}

Aesthetic Programming explores the technical as well as cultural imaginaries of programming from its insides. It follows the principle that the growing importance of software requires a new kind of cultural thinking - and curriculum - that can account for, and with which to better understand the politics and aesthetics of algorithmic procedures, data processing and abstraction. It takes a particular interest in power relations that are relatively under-acknowledged in technical subjects, concerning class and capitalism, gender and sexuality, as well as race and the legacies of colonialism. This is not only related to the politics

of representation but also nonrepresentation: how power differentials are implicit in code in terms of binary logic, hierarchies, naming of the attributes, and how particular worldviews are reinforced and perpetuated through computation. Using p5.js, it introduces and demonstrates the reflexive practice of *aesthetic programming*, engaging with learning to program as a way to understand and question existing technological objects and paradigms, and to explore the potential for reprogramming wider eco-socio-technical systems. The book itself follows this approach, and is offered as a computational object open to modification and reversioning.

Aesthetic Programming maintains a commitment to the spirit of cooperation and collaboration central to FLOSS, enacted not only through the way the code contained within is shared and made accessible, but in the design and publication of the book itself as a 'dynamic object.' (...) The role of the design agency OpenSource Publishing (OSP) in the design of the book enacts, extends, and plays with these conceptual issues. The book was collaboratively written and formatted through code (Markdown), and managed using the version-control system Gitand indeed the authors use the word 'Git' to open up a bigger discussion about the problematic terminologies embedded in programming 
Sources: https://www.aesthetic-programming.net, and Young,2021.

Reviews/Forks: Marino, 2021, and Marino \& Ciston,2021.

The Turing Way Community, Becky Arnold, Louise Bowler, Sarah Gibson, Patricia Herterich, Rosie Higman, ... Kirstie Whitaker. (2019, March 25). The Turing Way: A Handbook for Reproducible Data Science (Version v0.0.4). Zenodo. http://doi.org/10.5281/zenodo.3233986

The Turing Way is an open source community-driven guide to reproducible, ethical, inclusive and collaborative data science. Its goal is to provide all the information that data scientists in academia, industry, government and the third sector need at the start of their projects to ensure that they are easy to reproduce and reuse at the end.The book started as a guide for reproducibility, covering version control, testing, and continuous integration. However, technical skills are just one aspect of making data science research "open for all." In February 2020, The Turing Way expanded to a series of books covering reproducible research, project design, communication, collaboration, and ethical research. This project is openly developed and any and all questions, comments and recommendations are welcome at our github repository. The book is collaboratively written and open from the start. To make this project truly accessible and useful for everyone, we invite you to contribute your skills and bring your perspectives into this project. To join this community, please read our contribution guidelines and ways to get in touch. More information about the community and the project is available in the Community Handbook. We look forward to expanding and building The Turing Way together.

Source: The Turing Way Community,2019.

\section{Enhanced Books}

Books in standard print or PDF codex format that have been enriched with additional information, including open, online available data sets, resources, and other multimodal and interactive content (e.g., audio and video). Also: enriched publications, augmented books.

Hobson, M., Tunstall, K. E., Warman, C., \& Duc, P. (2016). Denis Diderot 'Rameau's Nephew' - 'Le Neveu de Rameau': A Multi-Media Bilingual Edition (P. Duc, Trans.). Open Book Publishers. https://doi.org/10.11647/OBP.0098

Incorporates specially-recorded musical pieces into the body of the text, offering a sensory and scholarly evocation of Diderot's work for a general audience. See here, for instance. Probably completed in 1772-73, Denis Diderot's Rameau's 
Nephew fascinated Goethe, Hegel, Engels and Freud in turn, achieving a literaryphilosophical status that no other work by Diderot shares. This interactive, multimedia and bilingual edition offers a brand new translation of Diderot's famous dialogue, and it also gives the reader much more. Portraits and biographies of the numerous individuals mentioned in the text, from minor actresses to senior government officials, enable the reader to see the people Diderot describes, and provide a window onto the complex social and political context that forms the backdrop to the dialogue. Links to musical pieces specially selected by Pascal Duc and performed by students of the Conservatoire national supérieur de musique et de danse de Paris, illuminate the wider musical context of the work, enlarging it far beyond its now widely understood relation to opéra comique.

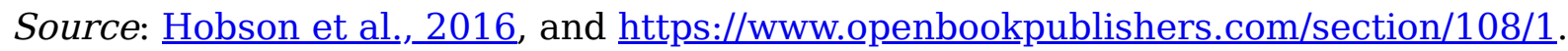

\section{Paim, J. S. (2015). O que é o SUS: E-book interativo. Editora Fiocruz.} http://www.livrosinterativoseditora.fiocruz.br/sus/

A luta pelo direito à saúde e pela consolidação do Sistema Único de Saúde (SUS) tem se expressado a partir da articulação de trabalhadores das áreas da saúde, pesquisadores e militantes dos movimentos sociais nas últimas décadas. O livro $O$ Que É o SUS - um dos títulos mais procurados da Editora Fiocruz, já tendo sido reimpresso cinco vezes - busca esclarecer o que é, o que não é, o que faz, o que deve fazer e o que pode fazer o SUS. Pela importância do tema e da obra, $O$ Que É $o$ SUS foi selecionado para se transformar no primeiro e-book interativo da Editora Fiocruz, no âmbito do primeiro edital da Faperj especialmente dedicado às editoras universitárias. O objetivo do projeto não era mudar o suporte do papel para a tela, mas oferecer uma nova experiência de leitura, onde vídeos, áudios, galerias de fotos, infográficos e outros recursos ora complementassem, ora substituíssem partes do texto original, criando uma nova textualidade eletrônica. O resultado é fruto de uma construção coletiva e, antes, do consentimento do autor, o professor da Ufba Jairnilson Silva Paim, que, generosamente, seguiu "o exemplo de João Ubaldo Ribeiro de não interferir na transformação de seus livros em filmes, novelas ou mini-séries, pois, além de outras linguagens, na realidade, tais iniciativas expressam novas criações", nas palavras do próprio sanitarista. Uma nova criação que, assim como o livro de 2009, busca contribuir para a consolidação, o fortalecimento e a expansão do SUS.

Source: Paim, 2015. 


\section{Babini, D., \& Rovelli, L. (2020). Tendencias recientes en las políticas científicas de ciencia} abierta y acceso abierto en Iberoamérica. CLACSO : Fundación Carolina.

El propósito general del informe busca reconstruir y analizar el estado de las investigaciones y las políticas científicas en acceso abierto, datos abiertos de investigación y ciencia abierta en Iberoamérica e indagar su incidencia en la evaluación de trayectorias investigativas, publicaciones científicas e indicadores de impacto. Con ello, CLACSO y la Fundación Carolina persiguen contribuir desde el desarrollo de conocimientos locales y situados al tratamiento y posible resolución de los grandes desafíos planteados por los Objetivos de Desarrollo Sostenible de la Agenda 2030.

This new book is the first book in CLACSO's interoperable (OAI-PMH) digital repository http://biblioteca.clacso.edu.ar/ with interactive links in footnotes, and interactive links to open access references in the bibliography.

Source: Babini \& Rovelli, 2020, and private email conversation.

Jenkins, H., Shresthova, S., Gamber-Thompson, L., Kligler-Vilenchik, N., \& Zimmerman, A. (2016). By Any Media Necessary: The New Youth Activism. NYU Press. http://hdl.handle.net/2333.1/brv15j $\underline{\text { 8}} \underline{p}$

Open Square is NYU Press's platform for publishing and reading open access books. A browser-based reading platform, Open Square enables us to increase the impact of scholarly work by making it freely available in a digital format and to experiment with new ways of presenting scholarship and adding enhanced content to traditionally published books. This site uses Readium, an open source software package for handling EPUB documents. By Any Media Necessary offers a profoundly different picture of contemporary American youth. Young men and women are tapping into the potential of new forms of communication such as social media platforms, spreadable videos and memes, remixing the language of popular culture, and seeking to bring about political change-by any media necessary.

Source: NYU Press: About Open Square and NYU Press: Connected Youth.

Ganahl, S. (2022). Campus Medius: Digital Mapping in Cultural and Media Studies. https://www.transcript-publishing.com/978-3-8376-5601-5/campus-medius-digitalmapping-in-cultural-and-media-studies/ and https://campusmedius.net/

Campus Medius explores and expands the possibilities of digital cartography in cultural and media studies. Simon Ganahl documents the development of the 
project from a historical case study to a mapping platform. The first section presents the initial version (1.0/2014) of campusmedius.net, an interactive map with a timeline displaying fifteen events within twenty-four hours in Vienna on the weekend of May 13 and 14, 1933. The second part discusses the current version (2.0/2021) of the project that additionally focuses on the main event of this exemplary time-space or chronotope: an Austrofascist "Turks Deliverance Celebration" (Türkenbefreiungsfeier) in the gardens of Schönbrunn Palace, which is imparted from a bird's-eye perspective, panoramically, and in street view by five mediators each. The following section deals with the technological infrastructure and the data model of Campus Medius, which operationalizes the theoretical concepts of the dispositif and the actor-network. In conclusion, we outline our plans to establish a digital platform for describing and visualizing media experiences in everyday life.

Source: Ganahl, 2022, and https://campusmedius.net/overview

Phone \& Spear: A yuta anthropology. (2019). https://www.gold.ac.uk/goldsmithspress/publications/phone-and-spear-/ and https://phone-and-spear.pubpub.org/

Building on a ten-year collaboration by the community-based arts collective Miyarrka Media, the project is an experiment in the anthropology of co-creation. It is a multivoiced portrait of an Indigenous society using mobile phones inventively to affirm connections to kin and country amid the difficult and often devastating circumstances of contemporary remote Aboriginal life. But this is not simply a book about Aboriginal art, mobile phones, and social renewal. If old anthropology understood its task as revealing one world to another, yuta anthropology is concerned with bringing different worlds into relationship. Following Yolngu social aesthetics - or what Miyarrka Media translate as "the law of feeling" - the book is a relational technology in its own right: an object that combines colour, pattern, and story to bring once distant worlds into new sensuously mediated connections.

Source: Phone \& Spear: A Yuta Anthropology, 2019

Boluk, S., \& LeMieux, P. (2017). Metagaming: Playing, competing, spectating, cheating, trading, making, and breaking videogames. University of Minnesota Press. https://manifold.umn.edu/projects/metagaming

Boluk and LeMieux shine a hundred spotlights on play's diversity in, on, around, between, through, and without video games. Their wildly eclectic book careens from competitive e-sports and video game spectatorship to hacking, modding, speedrunning, experimenting, and critiquing video games-all valid ways of 
engaging with the medium that tend to fall outside analyses which see these activities as merely the metagame.

Source: Boluk \& LeMieux, 2017.

\section{Experiments in Authorship}

Books that are exploring different forms of authorship, i.e., collaborative, distributed, communal, machinic, or anonymous, often as a critique of the ways in which authorship currently functions within academia.

Uncertain Commons. (2013). Speculate This! Duke University Press. https://www.dukeupress.edu/Speculate-This/ and https://speculatethis.pressbooks.com/

As a collaborative work coauthored by a group of anonymous scholars, Speculate This! argues for and embodies affirmative speculation. A short, timely manifesto critiquing predatory modes of financial speculation that seek to minimize uncertainty and risk, while advocating speculative practices that embrace uncertainty, spur radical change, and enable alternative futures. The uncertain commons is a group of scholars, mediaphiles, and activists who explore the possibilities of collaborative intellectual labor. They remain anonymous as a challenge to the current norms of evaluating, commodifying, and institutionalizing intellectual labor. Members of the group represent a diverse set of nationalities, backgrounds, and institutional affiliations, and they participate in a range of disciplines, including cultural studies, English, media studies, philosophy, Middle Eastern studies, and South Asian studies.

Source: Uncertain Commons, 2013.

The Multigraph Collective. (2018). Interacting with Print: Elements of Reading in the Era of Print Saturation. University of Chicago Press. https://doi.org/10.7208/chicago/9780226469287.001.0001

The Multigraph Collective is a team of twenty-two scholars at sixteen universities in Canada, the US, and the UK. Its members are Mark Algee-Hewitt, Angela Borchert, David Brewer, Thora Brylowe, Julia Carlson, Brian Cowan, Susan Dalton, Marie-Claude Felton, Michael Gamer, Paul Keen, Michelle Levy, Michael Macovski, Nicholas Mason, Nikola von Merveldt, Tom Mole, Andrew Piper, Dahlia Porter, Jonathan Sachs, Diana Solomon, Andrew Stauffer, Richard Taws, and Chad Wellmon. As the larger group came together, Piper had the idea of disseminating the work through an ambitious collaboration: a jointly authored book that would draw on everyone's research interests, with writing and editing undertaken 
electronically, via wiki software. Anyone would be able to write or revise, insert or delete, expound or qualify. The book wouldn't have one author but 22, each taking responsibility for all of its contents: instead of a monograph, it would be a "multigraph." (The word wasn't Piper's originally, but it fit.) And so a massive collaborative enterprise-which came to be called the Multigraph Collective-was born.

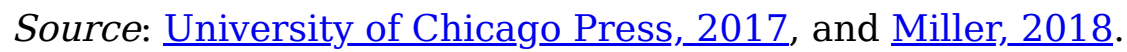

\section{Anon Collective (2021) Book of Anonymity. punctum books. https://punctumbooks.com/titles/book-of-anonymity.}

Anonymity is highly contested, marking the limits of civil liberties and legality. Digital technologies of communication, identification, and surveillance put anonymity to the test. They challenge how anonymity can be achieved, and dismantled. Everyday digital practices and claims for transparency shape the ways in which anonymity is desired, done, and undone. The Book of Anonymity includes contributions by artists, anthropologists, sociologists, media scholars, and art historians. It features ethnographic research, conceptual work, and artistic practices conducted in France, Germany, India, Iran, Switzerland, the UK, and the US. From police to hacking cultures, from Bitcoin to sperm donation, from Yik-Yak to Amazon and IKEA, from DNA to Big Data - thirty essays address how the reconfiguration of anonymity transforms our concepts of privacy, property, self, kin, addiction, currency, and labor.

The Book of Anonymity is written in the tradition of author-less texts. Editing and contributing anonymously constitute experiments in anonymity that speak to the aggressive valuation regimes shaping contemporary artistic and academic knowledge productions alike. This is not to discount the usefulness of attribution, but to trouble the ease with which labour is still dissected, measured and attached to the nexus of person, value and knowledge. To name, one contribution insists is to "define people, things, as individuals, to mark them, hold them, hierarchize them, to press them into service and turn them into value." Another contribution advocates and questions if an ethics of anonymity can engender the kind of care that individualised practices arguably strive for yet undermine. Not all contributions speak to such concerns directly but all consider what is at stake in the im/possibilities of anonymous expression, at a time of thick digital traces. Editing and contributing anonymously thus is a practical commitment to one of the red threads that criss-cross the kaleidoscopic accounts presented in this book. 
Source: Anon Collective, 2021.

\section{Experimental Design Books}

Books in which the design performs a central part of the argument.

\section{Hayles, N. K., Burdick, A., Loyer, E., Lunenfeld, P. (2002). Writing machines. MIT Press. https://mitpress.mit.edu/sites/default/files/titles/content/mediawork/titles/writing/writi ng_book.html}

Tracing a journey from the 1950s through the 1990s, N. Katherine Hayles uses the autobiographical persona of Kaye to explore how literature has transformed itself from inscriptions rendered as the flat durable marks of print to the dynamic images of CRT screens, from verbal texts to the diverse sensory modalities of multimedia works, from books to technotexts. The primary significance of Writing Machines, and any discussion of it, resides in the relationship between its material design and its argument for material criticism. The book's design not only embodies, but enables its argument. Form and content, mind and body, are not only inseparable, but are interdependent.

Anne Burdick:

I had always meant for the book design to be integral to the intellectual argument: it should not only interpret the argument, but should actively interrogate its terms. As a result, structures that are a component of the writing strategy became inseparable from the design strategy, and vice versa. The three most significant manifestations of this are in the typefaces that identify different voices, the representational and navigational elements that emphasize the book's status as a book, and the sampled quotations-with their original materiality somewhat intactthat interweave with Kate's writing.

Source: Pressman, 2002, and https://mitpress.mit.edu/sites/default/files/titles/content/mediawork/titles/writing/writin g_book.html\#.

Miller, P. D., COMA, \& Hally, P. (2004). Rhythm Science (1st ed.). The MIT Press. https://mitpress.mit.edu/sites/default/files/titles/content/mediawork/titles/rhythm/rhyt hm book.html

Miller's textual provocations are designed for maximum visual and tactile seduction by the international studio COMA (Cornelia Blatter and Marcel Hermans). They sustain the book's motifs of recontextualizing and relayering, 
texts and images bleed through from page to page, creating what amount to 2.5 dimensional vectors. From its remarkable velvet flesh cover, to the die cut hole through the center of the book, which reveals the colored nub holding in place the included audio CD, Rhythm Science: Excerpts and Allegories from the Sub Rosa Archives, this pamphlet truly lives up to the Mediawork Pamphlets claim to be "theoretical fetish objects... 'zines for grown-ups."

Source: $\underline{\text { Miller et al., } 2004 .}$

McLuhan, M., Fiore, Q., \& Agel, J. (1967). The Medium is The Massage. Gingko Press. http://archive.org/details/pdfy-vNiFct6b-L5ucJEa

Fiore described The Medium is the Massage as having "no "original" manuscript. The idea was to select some of McLuhan's ideas from previous publications and present them in isolated 'patches' on individual spreads with accompanying artwork.' The major sources for the book were McLuhan's 1962 Gutenberg Galaxy and 1964 Understanding Media, the two texts that were gaining him notoriety for their aphoristic style and unqualified assertions. The most striking aspect of The Medium is the Massage, however, is the way it explores the space of the book - its literal scale and sequential unfolding - as part of its content. For instance, the full-bleed images that introduce an idea on one spread are repeated on the following spread at postage stamp size. This structure, repeated across several pages, encourages the images to be read differently according to their scale and juxtaposition to other images and words. Fiore's layouts destabilise the traditional hierarchy of image and caption, text and illustration. Elsewhere, Fiore highlights the literal dimension of the book with a spread showing the thumbs of the reader holding the pages open: a photographic doubling of the reader's own hands.

Source: $\underline{\text { Miller et al.,1993. }}$

Tsing, A.L., Deger, J., Keleman Saxena, A., and Zhou, F. (eds.) (2021) Feral Atlas: The More-ThanHuman Anthropocene. Stanford University Press. http://feralatlas.org

Feral Atlas invites you to explore the ecological worlds created when nonhuman entities become tangled up with human infrastructure projects. Seventy-nine field reports from scientists, humanists, and artists show you how to recognize "feral" ecologies, that is, ecologies that have been encouraged by human-built infrastructures, but which have developed and spread beyond human control. These infrastructural effects, Feral Atlas argues, are the Anthropocene. Playful, 
political, and insistently attuned to more-than-human histories, Feral Atlas does more than catalog sites of imperial and industrial ruin. Stretching conventional notions of maps and mapping, it draws on the relational potential of the digital to offer new ways of analyzing-and apprehending - the Anthropocene; while acknowledging danger, it demonstrates how in situ observation and transdisciplinary collaboration can cultivate vital forms of recognition and response to the urgent environmental challenges of our times.

DESIGNED AND BUILT BY - Lili Carr (Map Director); School: Andrew Herzog and Nicky Tesla, with Emma Rae Bruml Norton, Lukas Eigler-Harding, Rahul Shinde; Art Camp: Santiago Carrasquila, Jos Diaz Contreras, Eugene Lee, Ningfeng Zhao, Heewon Kim; Victoria Baskin Coffey (Visual Editor); Jovan Maud (Copy and Digital Editor); Gabby Miller (Wrangler).

Source: Tsing, A. L., Deger,_J., Saxena, A. K., \& Zhou, F., 2020

\section{Experiments in Reviewing}

Books which have undergone online, open, community, or crowd-sourced forms of review, either during the research or publication phase or post-publication.

Fitzpatrick, K. (2011). Planned obsolescence: Publishing, technology, and the future of the academy. New York University Press. https://mcpress.mediacommons.org/plannedobsolescence/

Planned Obsolescence was openly reviewed using CommentPress, a blog-based publishing engine developed by the Institute for the Future of the Book, which seeks to promote dialogue within and around long-form texts in two primary ways: first, by structuring those texts around chunks that can be interlinked in linear and non-linear fashions, and that can take advantage of the ability to link to (and receive links from) other such texts in the network; and second, by allowing those chunks of texts to be commented and discussed at various levels of granularity, ranging from the document as a whole, to the page, all the way down to the paragraph. More recently, Fitzpatrick has published a new book, Generous Thinking: The University and the Public Good, which she has also developed in an open way by a process of community review, still using the CommentPress plugin, but now on the Humanities Commons platform: http://generousthinking.hcommons.org/

Source: Planned Obsolescence “Commentpress," 2009. 
Yates-Doerr, E., \& Labuski, C. (2017). The Ethnographic Case. Mattering Press. https://doi.org/10.28938/995527744 and https://www.matteringpress.org/books/theethnographic-case

The Ethnographic Case is an experimental, online, Open Access book, that invites readers to interact with it in a process of post-publication peer review (using the CommentPress plugin). The book challenges a widespread academic inclination to treat concepts as immutable mobiles. The contributions to this volume develop "ethnographic casing" as a technique of attending to heterogeneities in systems of thought.

Source: Yates-Doerr \& Labuski,_2017, and https://www.matteringpress.org/books/theethnographic-case

\section{Language Science Press post-publication community-review process}

Once the book is published, we make it available on our website, but also on a

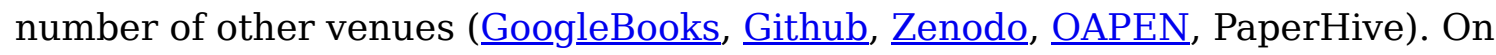
PaperHive, it is possible to leave comments on the published version of books. There are two main use cases for this: Errata and discussion points. The real goal of PaperHive, however, is to stimulate discussion about a book and to provide additional perspectives. (...) by making preliminary versions available for comment on a platform like PaperHive in a structured way, and by keeping a history of the different interlinked versions, the format "book" can actually be very well integrated into an electronic and collaborative publishing landscape.

Today, we can showcase docLoop, which allows us to transform the community comments into todo lists on GitHub, closing the loop from author to reader and back from the reader to the author. Our traditional workflow requires that authors go through the PaperHive document and take care of the comments as they go along, updating their manuscript. With docLoop, however, we can now harvest all those comments and put them in a nice GitHub issue list. Readers do not have to learn anything about git, though. They can simply use the very user-friendly PaperHive web interface to leave their feedback. This feedback is then converted into structured issues for further processing.

Sources: Nordhoff, 2017, and Nordhoff, 2020.

\section{Database books}

Books where a database of resources forms the central element (i.e., not as an enhancement to a text-based book) around which the book is formed. These can be non- 
linear, with multiple access points, or can incorporate updates or versioning, akin to a 'living archive'. Considers the question when is something a digital archive, and when is it a publication, or a book?

\section{Wernimont, J., Kim, D. J., Schonberg, S., Borsuk, A., Schuster, B., Blackmore, H., \& Gosart (Popova), U. (2018). Performing Archive: Curtis + "the vanishing race". Scalar. https://scalar.usc.edu/works/performingarchive/index}

Created as a pilot project for the Claremont Center for Digital Humanities, "Performing_Archive: Edward S. Curtis + 'the vanishing_race'” aggregates media from several different collections based on the early 20th century ethnographic and photographic work of Edward S. Curtis. At its core it is an aggregation of several existing archival visual, material, and sonic collections based on the work of Curtis, an early 20th century photographer. In its gathering of materials from multiple sources, "Performing Archive" acts both as a meta-archive in its own right, and as an interpretive layer that examines Curtis' materials through essays written by a variety of contributors. The project is designed to expand over time with additional contributions from students, faculty, and the public. "Performing Archive" is the first project to make use of an experimental new reader interface for Scalar that's designed to improve readability, navigation, and media presentation. In addition to aggregating nearly 2,500 items related to Curtis and his ethnographic and photographic work with western American and Canadian tribes, our "archive" also brings together a number of new scholarly works designed to facilitate teaching with Curtis' work. The issues of intellectual and cultural property rights raised by the publication of the Curtis images (both historically and now) are worth thinking about in broad terms as efforts within Digital Humanities, Public Humanities, and Museum Studies continues to engage in efforts to increase access to archives and collections that have been marginalized, excluded, or silenced.

Sources: Introducing_Performing_Archive: Edward S. Curtis + 'the Vanishing_Race',_ $\underline{2013}$, and "Introduction," n.d.

\section{Hybrid books}

Hybrid books exists in a plurality of formats or media, both digital and non-digital, online and offline. Often a print version for sale supports the other formats. Also: postdigital books, transmedia books, binding media. 
Zylinska, J., Kuc, K., Shaw, J., Varney, R., \& Wamposzyc, M. (2015). Photomediations: An Open Book. http://photomediationsopenbook.net/

Photomediations: An Open Book was an experiment in open and hybrid publishing, as well as a celebration of the book as living object. As part of its basic premise, it redesigned a coffee-table photography book as an online experience.

Photomediations adopted a process- and time-based approach to images by tracing the flows of data that produce photographic objects. This stance was reflected in the set-up of this open and hybrid book. Photomediations used open reusable image content, drawn from various open online repositories such as Europeana and Flickr Commons. In this way, the book showcased the possibility of the creative reuse of image-based digital resources. Photomediations: An Open Book consisted of a comprehensive introduction and four commissioned chapters on light, movement, hybridity and networks. The book also contained three open chapters, the content of which developed and grew over time, most notably into a collection of twenty scholarly and curatorial essays about the idea of photomediations, called Photomediations: A Reader, which was published as a standalone physical book by Open Humanities Press. Photomediations: An Open Book's final chapter consisted of an offline and online exhibition. The offline remixable flatpack exhibition, exhibited at Hamburger Bahnhof in Berlin, featured the work of nineteen international artists who responded to the project's open callto-action to liberate the image in the twenty-first century. The Photomediations project also encompassed an online Educational Space. It included a downloadable brochure titled A Guide To Open And Hybrid Publishing, which explained how anyone can undertake a project of this kind for themselves, a pack of Creative Jam Cards, based on four sets of creative tasks, that could be remixed to incorporate further questions and interventions, and a 'remix generator', which was designed to provide learners with an introduction to the basic processes and concepts of gathering and remixing open images, by offering a pool of open tasks and content.

Sources: Zylinska, 2015, and A Guide To Open And Hybrid Publishing, 2014, and Kuc \& Zylinska, 2016.

\section{Interactive Books}

Books that require reader participation or interaction, or that offer navigational possibilities to readers. Also: hypertext, webtext, or Interactive Scholarly Work 


\section{Bauch, N. (2016). Enchanting the Desert: A Pattern Language for the Production of Space. http://www.enchantingthedesert.com/home/}

Enchanting the Desert is the geographical revival of Henry Peabody's travelling Grand Canyon slide-show made in the early part of the twentieth century. It helped set a template for how we see the Grand Canyon today. Using an established medium - the website application-Enchanting the Desert introduces a genre of scholarship-the born-digital interactive monograph. The medium allows for technical leaps impossible in a print publication. The genre takes advantage of these leaps by performing spatial narrative in an inventive new way. Enchanting the Desert contributes to an aesthetic for the production of cultural space. It is a conversation between two modes of visual geographic representation: the pictorial and the cartographic. Holding these two in concert is to explore between emotion and analysis.

Source: Bauch, 2016.

Kolb, D. (1994). Socrates in the labyrinth: Hypertext, Argument, Philosophy. Eastgate Systems. http://www.eastgate.com/catalog/Socrates.html

Socrates in the Labyrinth is a wide-ranging exploration of the relationships between hypertext, thought, and argument. Does hypertext present alternatives to the logical structures of if-then, claim and support? Is hypertext a mere expository tool, that cannot alter the essence of discussion and proof? Or is hypertext essentially unsuited to rigorous argument? Kolb's discussion is a nuanced, creative approach to these and other questions. Kolb points up the history of nonlinearity in philosophical work, from the Socratic dialogues through Hegel, and the variety of forms that philosophical discussion can take. Kolb's discussion -and the structures of Socrates itself -- show that hypertext is not only a "superencyclopedia" that leaves the essence of argument unchanged. But his keen understanding of both hypertext and postmodernism also shows that the relation between hypertext and "the end of the text" is more complex than is sometimes claimed. Socrates in the Labyrinth embodies several hypertext structures showing possibilities for writing and thought in the new medium. Socrates in the Labyrinth is one of the first works of hypertext non-fiction to examine and exploit the techniques of hypertext rhetoric discovered in the development of serious hypertext fiction. Socrates in the Labyrinth was created using Storyspace.

Source: $\underline{\text { Kolb }}, \underline{1994}$. 


\section{Greco, D. (1995). Cyborg: Engineering the body electric. Eastgate Systems. http://www.eastgate.com/catalog/Cyborg.html}

Diane Greco explores the significance of the cyborg in 20th century writing. from Thomas Pynchon and William Gibson to Haraway and Derrida. The cyborg is more than just an interesting fiction; Cyborg: Engineering The Body Electric explores cyborg's impact on political action and personal identity.

Source: $\underline{\text { Greco, }}, \underline{1995}$.

Paul, E., McKenzie, D., Raibmon, P., \& Johnson, H. (2019). As I Remember It: Teachings ( Pəms $t a$ Paw) from the Life of a Sliammon Elder. http://publications.ravenspacepublishing.org/asi-remember-it/index

With this immersive online publication adapted from Written as I Remember It, readers can learn about the Sliammon language, listen to Elsie tell her stories, and watch short animations of legends and events. They can navigate by theme Territory, Colonialism, Community, Wellness - explore the contents through interactive maps, browse the audio and visual galleries, or make use of the instructional materials designed for teachers and students.

This media-rich, multi-path book offers a rare glimpse into the life of a Coast Salish woman and the history and lifeways of her people. It stands as a model for collaborative research and digital storytelling. Accessible and engaging, it will be a welcome resource for anyone learning about the legacy of colonialism in Canada, the resilience of First Nations people, the possibilities of reconciliation, and the importance of sharing and listening.

Source: $\underline{\text { Paul et al.,2019. }}$.

\section{Living Books}

Books that are published on a Read/Write basis open to ongoing collaborative processes of writing, editing, updating, remixing and commenting by readers. These books continue to evolve over time as content is added. Also: liquid books, wiki-books.

\section{Living Books About Life. Open Humanities Press. http://www.livingbooksaboutlife.org/}

By creating twenty one 'living books about life' in just seven months, the series represents an exciting new model for publishing, in a sustainable, low-cost manner, many more such books in the future. These books can be freely shared with other academic and non-academic institutions and individuals. Taken together, they constitute an engaging interdisciplinary resource for researching 
and teaching relevant science issues across the humanities, a resource that is capable of enhancing the intellectual and pedagogic experience of working with open access materials. All the books in the series are themselves 'living', in the sense that they are open to ongoing collaborative processes of writing, editing, updating, remixing and commenting by readers. As well as repackaging open access science research -- along with interactive maps, visualisations, podcasts and audio-visual material -- into a series of books, Living Books About Life is thus engaged in rethinking 'the book' itself as a living, collaborative endeavour in the age of open science, open education, open data and e-book readers such as Kindle and the iPad.

Source: Liquid/Living Books.

Méndez Cota, G., Torres, L. E., Toxqui, M. \& Arziniaga, Á. (2016). En Busca del Quelite Perdido. Consejo Nacional para la Cultura y las Artes. https://web.archive.org/web/20180807002404/http:/enbuscadelqueliteperdido.com/

En busca del quelite perdido es un libro acerca de Cholula que se compone de un ensayo testimonial, un archivo fotográfico y un recetario. En esta página puedes acceder a los contenidos originales del libro, modificarlos y enriquecerlos con tu propio testimonio, tus propias recetas y tus propias fotografías. Se trata de un libro viviente: un texto múltiple y dinámico abierto a tu participación. El objetivo es fomentar y sostener una reflexión pública sobre los cambios que la urbanización trae a la vida cotidiana en Cholula, y sobre lo que podemos hacer para que sean algo más que una pérdida: un ejercicio colectivo de reinvención cultural.

Source: Méndez Cota et al., 2016.

\section{Living Books About History collection from infoclio.ch, from https://www.livingbooksabouthistory.ch/en/}

Les Living Books about History sont une collection d'anthologies numériques sur des thèmes de recherche actuels. Chaque livre contient un essai par les éditrices ou éditeurs, ainsi qu'une sélection de textes et de sources. Ces contributions peuvent être des articles, illustrations, vidéos, sites web ou enregistrements, qui existent pour la plupart déjà en libre accès sur internet. Le projet promeut l'Open Access dans les sciences humaines, en présentant sous une nouvelle forme des contributions librement accessibles sur le web. Les contenus disponibles en ligne sont soumis à des conditions d'utilisation hétérogènes. Afin de sensibiliser à la diversité des régimes juridiques et aux applications complexes des droits 
d'auteurs dans les sciences, chaque Living Book possède une section „Attribution“, qui détaille la référence bibliographique originale ainsi que les conditions d'utilisation pour chaque contribution. Voir aussi la section Droits d'auteur. Tous les Living Books about History sont disponibles dans leur langue originale ainsi qu'en Anglais.

Source: About: Living Books About History.

\section{BOOC (Books as Open Online Content). (2016-). UCLPress. https://ucldigitalpress.co.uk/BOOC}

This innovative new digital format presents subjects in the form of a 'living book' with articles of various types, in a non-linear thematic presentation that offers readers the option to select and sort subjects they wish to read. With long and short articles, blogs, videos, audio and Storifys, these 'books' are added to and grow over a period of time. Due to the nature of material featured in BOOC only certain types of content were subject to peer review. Non-traditional content such as videos and Storifys have been excluded from the peer review process. The Academic Book of the Future is the first BOOC to be published by UCL Press. More content will be added to BOOC in the near future.

Source: Rayner, 2017.

\section{Performative Books}

A publication in which 'the mode of publication performs one of the central ideas the text itself seeks to articulate and explore' (Long,2013). A performative publication wants to explore how we can bring together and align more closely the material form of a publication with its content. Performative publications focus on how the mode in which we produce, disseminate and consume text, influences the content and meaning of the text, or the way we interpret it. Also: webtext, technotext, liberature.

Juhasz, A. (2011). Learning From YouTube. MIT Press. http://vectors.usc.edu/projects/learningfromyoutube/

The MIT Press, in partnership with the Alliance for Networking Visual Culture, has just published Learning from YouTube (MIT Press, February 2011), by Alexandra Juhasz, Professor of Media Studies at Pitzer College in Claremont, California. YouTube is the subject, form, method, problem, and solution of her video-book: an online inquiry into today's media. This is not your typical scholarly book (Learning from YouTube can never go to paper) Juhasz writes about social media inside and through it. This video-book contains a series of more than 200 texts and videos 
-"texteos" - that encourage users to think about YouTube by experiencing and learning within this digital entertainment platform. Whether in video or textual form, Juhasz writes in a relatively informal voice suitable to her subject and the online digital format of the project permits contributions from its users.

Source: Juhasz, 2011.

Long, C. P. (2017). Socratic and Platonic Political Philosophy: Practicing a Politics of Reading. Cambridge University Press. https://www.cambridge.org/gb/academic/subjects/politicsinternational-relations/political-theory/socratic-and-platonic-political-philosophypracticing-politics-reading?format $=$ AR\&isbn $=9781139899048$

Recently, I have been working on two performative publications. The first, my enhanced digital book to be published by Cambridge University Press entitled: Socratic and Platonic Politics: Practicing a Politics of Reading, argues that Platonic writing is political in the sense that it is designed to cultivate a community of readers committed to integrating the question of the just, the beautiful and the good into their relationships with one another. By writing dramatic dialogues that depict an enigmatic Socrates engaged with idiosyncratic individuals, Platonic writing requires its readers to cultivate a hermeneutic imagination that, when applied to concrete human interactions, has the capacity to open new possibilities of more just and enriching relationships. By publishing it as an enhanced digital book that encourages its reader to share their annotations and participate with the author of the text in an ongoing conversation, the hope is to put the community of collaborative readers for which the book argues into practice.

Source: Long, 2013.

Kolb, D. (1994). Socrates in the labyrinth: Hypertext, Argument, Philosophy. Eastgate Systems. http://www.eastgate.com/catalog/Socrates.html

Socrates in the Labyrinth is a wide-ranging exploration of the relationships between hypertext, thought, and argument. Does hypertext present alternatives to the logical structures of if-then, claim and support? Is hypertext a mere expository tool, that cannot alter the essence of discussion and proof? Or is hypertext essentially unsuited to rigorous argument? Kolb's discussion is a nuanced, creative approach to these and other questions. Kolb points up the history of nonlinearity in philosophical work, from the Socratic dialogues through Hegel, and the variety of forms that philosophical discussion can take. Kolb's discussion -and the structures of Socrates itself -- show that hypertext is not only a "super- 
encyclopedia" that leaves the essence of argument unchanged. But his keen understanding of both hypertext and postmodernism also shows that the relation between hypertext and "the end of the text" is more complex than is sometimes claimed. Socrates in the Labyrinth embodies several hypertext structures showing possibilities for writing and thought in the new medium. Socrates in the Labyrinth is one of the first works of hypertext non-fiction to examine and exploit the techniques of hypertext rhetoric discovered in the development of serious hypertext fiction. Socrates in the Labyrinth was created using Storyspace.

Source: Kolb, 1994, and Grigar et al.,_2018.

\section{Remixed Books}

Books that consist of previously published materials that are remixed, reused or rewritten into a new publication (which often itself is open for remix again too).

Amerika, M. (2011). Remixthebook. U of Minnesota Press. http://www.remixthebook.com/

The remixthebook.com website is the online hub for the digital remixes of many of the theories generated in the print book and features the work of artists, creative writers and scholars for whom the practice and theory of remix art is central to their research interests. remixthebook author Mark Amerika, along with cocurator and artist Rick Silva, has invited over 25 contributing international artists, poets, and critical theorists, all of them interdisciplinary in their own practicebased research, to sample from remixthebook and manipulate the selected source material through their own artistic and theoretical filters.

Source: $\underline{\text { Amerika, } 2011 .}$

\section{OBP Customise. (n.d.). Open Book Publishers. https://www.openbookpublishers.com/section/59/1}

We can help you mix, match, and personalise. Take chapters or whole books from our published list and make a special edition, a new anthology, or an illuminating coursepack. Each customised edition will be produced as a paperback and a downloadable PDF. So long as you have copyright permission for non-OBP material, we would be delighted to create a new, composite book for you, complete with cover and introduction.

Source: $\underline{\text { OBP Customise, n.d. }}$ 


\section{Versioned Books}

Books that are published in different versions or in a processual, iterative manner. Also: processual books, iterative books

Wark, M. (2007). Gamer theory. Harvard University Press. http://futureofthebook.org/mckenziewark/index.html

- Version 1.1: http://futureofthebook.org/gamertheory/

- Version 2.0: http://futureofthebook.org/gamertheory2.0/

- Version 2.1: https://www.hup.harvard.edu/catalog.php?isbn=9780674025196

- Version 3.0:

\section{http://futureofthebook.org/mckenziewark/visualizations/index.html}

Together with the Institute for the Future of the Book I produced this website as a way to think about games. We released Version 1.1 back in 2006. Based on the many thoughtful and careful comments people made on it, I revised Gamer Theory and came up with Version 2.0, which is available here. Comments on Version 1.1 are now closed, but we welcome comments and discussion here at Version 2.0. Together with the Institute for the Future of the Book, I thought it would be interesting to make Version 2.0 of my book Gamer Theory available for people who would like to visualize it. So now we have a Version 2.0 here on the web that people can comment on, and a Version 2.1 in print form from Harvard University Press for people who like a well designed and elegantly produced artifact, and we also have what I think of as Version 3 of Gamer Theory - the visualizations. These pose the question of what digital technology can bring to the presentation of text.

Source: Wark, 2007.

Trettien, W. (n.d.). Cut/Copy/Paste. Fragments of History. University Of Minnesota Press. https://manifold.umn.edu/projects/cut-copy=paste

Cut/Copy/Paste explores the relations between fragments, history, books, and media. It does so by scouting out fringe maker cultures of the seventeenth century, where archives were cut up, "hacked," and reassembled into new media machines.

An overarching goal of this project-limned in greater detail in the abstract above -is to demonstrate how using digital technologies as bibliographic research tools challenges and changes the kinds of stories we might tell about early modern readers, writers, books, and their publishers. Toward that end, I am staging this 
draft digitally, so that you might explore some of the images, datasets, maps, graphs, and social networks that undergird my claims about Edward Benlowes as a publisher of boutique printed books. Other chapters on Little Gidding and John Bagford will be made available in this space, too, as this project progresses.

Source: $\underline{\text { Trettien, }}$ n.d.

Barral-Netto, M., Barreto, M. L., Pinto Junior, E. P., \& Aragão, E. (2020). Construção de conhecimento no curso da pandemia de COVID-19: Aspectos biomédicos, clínicoassistenciais, epidemiológicos e sociais. EDUFBA. http://repositorio.ufba.br/ri/handle/ri/32370

Com o objetivo de sistematizar um produto acadêmico com conhecimentos sobre a pandemia da covid-19, pesquisadores da Rede CoVida lançam um e-book gratuito nesta quinta-feira (17), às $16 \mathrm{~h}$. Intitulada "Construção de Conhecimento no curso da pandemia de Covid-19: aspectos biomédicos, clínico-assistenciais, epidemiológicos e sociais”, a obra poderá ser usada como material de didático por pesquisadores, professores e estudantes. A Rede CoVida é uma iniciativa que surgiu em março de 2020, a partir da união entre o Centro de Integração de Dados e Conhecimentos para Saúde (Cidacs/Fiocruz Bahia) e a Universidade Federal da Bahia (Ufba), diante da maior crise de sanitária global dos últimos 100 anos. Pesquisadores e profissionais da comunicação se uniram para oferecer informações científicas confiáveis que ajudassem gestores e a sociedade na tomada de decisões seguras sobre a Covid-19. Um segundo volume, que já está em fase de produção, abordará os temas relacionados à assistência à saúde, epidemiologia e questões sociais ligadas à pandemia. "A ideia foi produzir um ebook em um formato mais flexível, permitindo que sejam incluídos novos capítulos no curso da pandemia, que continua em curso, e como ela, buscas de explicações científicas e resultados de pesquisas, cuja produção se encontra em franca expansão", explica o pesquisador Manoel Barral Netto.

Source: $\underline{\text { dos Anjos, } 2020 .}$.

Lessig, L. (2006). Code (Version 2.0). Basic Books. https://web.archive.org/web/20190314234037/http://www.codev2.cc/ and https://www.socialtext.net/codev2/

Lessig's "Code and Other Laws of Cyberspace" was published in 1999. The book quickly began to define a certain vocabulary for thinking about the regulation of cyberspace. More than any other social space, cyberspace would be controlled or not depending upon the architecture, or "code," of that space. And that meant 
regulators, and those seeking to protect cyberspace from at least some forms of regulation, needed to focus not just upon the work of legislators, but also the work of technologists. Code v2 updates the original work. It is not, as Lessig writes in the preface, a "new work." Written in part collectively, through a Wiki hosted by JotSpot, the aim of the update was to recast the argument in the current context, and to clarify the argument where necessary. Code v2 is licensed under a Creative Commons Attribution-ShareAlike 2.5 License license. It can therefore be freely downloaded and shared. Modifications must be similarly licensed. All royalties from the book will go to support Creative Commons. And the current version is now available on a wiki to be updated and corrected as the community of readers believes best.

Source: Lessig, 2019.

Schäfer, R. (2018). Einführung in die grammatische Beschreibung des Deutschen: Dritte, überarbeitete und erweiterte Auflage. Language Science Press. https://langscipress.org/catalog/book $/ 224$

Die dritte Auflage behebt Tipp- und Stilfehler und bietet einige neue Vertiefungsblöcke sowie eine komplette Überarbeitung der Grafiken und Diagramme. Ein Kapitel über Grammatik in Schule und Lehramtsstudium ergänzt das Buch.

Back in 2017, we wrote a blog_post on fluid publication. This explained the development of a book by the author together with the readership, reusing techniques well-known from software development. The author 1) starts with a draft version, collects feedback from colleagues, and then the stages of 2) (open) review, 3) acceptance, 4) community proofreading and finally 5) publication of the first edition follow. A history of the different versions is kept on GitHub. GitHub also provides functionalities to manage lists of open issues which still have to be addressed before the next stage can be initiated. Iterative publication does not end with the first edition, as explained in our 2017 blogpost. Readers will have feedback, and Paperhive allows us to collect this feedback.

Source: Nordhoff, 2020. 


\section{LIBER Citizen Science Working Group (2021) Citizen Science Skilling for Library Staff, Researchers, and the Public. LIBER Citizen Science Working Group. https://cs4rl.github.io/guide/\#}

A practical guide designed to assist those organising and participating in a citizen science project to get the most out of the experience. The guide will enable you to have the skills to ensure a project is well set up from the start, is able to communicate to its stakeholders and citizens, manage its data and outputs, and overall ensure research benefits. The guide has been compiled by the LIBER Citizen Science Working Group and pulls on the generous contributions of the open science community. The book is intended as a short guide and will be approximately one hundred pages in length. The publication will be produced as multi-format and multi-channel (print-on-demand, PDF, Webbook, website, eBook, and as a Jupyter Book - and will be technically designed for reuse, for example in community translations or in MOOCs. Book sections will be released incrementally as they are ready. Ideally, the book will become a community-owned publication with regular updates.

Source: Hansen,_J. S., Kaarsted, T., \& Worthington, S., 2021.

\section{References:}

A Guide To Open And Hybrid Publishing - Centre for Disruptive Media. (2014). https://www.europeana-space.eu/wpcontent/uploads/2014/04/Guide to Open and Hybrid_Publishing.pdf

About: Living Books About History. (n.d.). Retrieved 27 January 2021, from https://www.livingbooksabouthistory.ch/en/about

Amerika, M. (2011). Remixthebook. U of Minnesota Press. http://www.remixthebook.com/

Anon Collective. (2021). Book of Anonymity. punctum books. https://doi.org/10.21983/P3.0315.1.00

Babini, D., \& Rovelli, L. (2020). Tendencias recientes en las políticas científicas de ciencia abierta y acceso abierto en Iberoamérica. CLACSO : Fundación Carolina.

Barral-Netto, M., Barreto, M. L., Pinto Junior, E. P., \& Aragão, E. (2020). Construção de conhecimento no curso da pandemia de COVID-19: Aspectos biomédicos, clínicoassistenciais, epidemiológicos e sociais. EDUFBA. http://repositorio.ufba.br/ri/handle/ri/32370 
Bauch, N. (2016). Enchanting the Desert: A Pattern Language for the Production of Space. http://www.enchantingthedesert.com/home/

Boluk, S., \& LeMieux, P. (2017). Metagaming: Playing, competing, spectating, cheating, trading, making, and breaking videogames. University of Minnesota Press. https://manifold.umn.edu/projects/metagaming

Cox, G., \& Soon, W. (2021). Aesthetic Programming-A Handbook of Software Studies. https://www.aesthetic-programming.net/

dos Anjos, A. (2020, December 15). Rede CoVida lança primeiro e-book com conhecimentos sobre a pandemia da Covid-19. Rede Covida - Ciência, Informação e Solidariedade. https://redecovida.org/2020/12/15/rede-covida-lanca-primeiro-e-bookcom-conhecimentos-sobre-a-pandemia-da-covid-19-em-evento-online/

Enchanting the Desert. (2016). http://www.enchantingthedesert.com/home/

Fitzpatrick, K. (2009, August 30). 'Commentpress'. Planned Obsolescence. https://mcpress.media-commons.org/plannedobsolescence/three-texts/commentpress/

Fitzpatrick, K. (2011). Planned obsolescence: Publishing, technology, and the future of the academy. New York University Press. https://mcpress.mediacommons.org/plannedobsolescence/

Ganahl, S. (2022). Campus Medius: Digital Mapping in Cultural and Media Studies. https://www.degruyter.com/isbn/9783839456019 \& https://campusmedius.net/ Greco, D. (1995). Cyborg: Engineering the body electric. Eastgate Systems. http://www.eastgate.com/catalog/Cyborg.html

Hansen, J. S., Kaarsted, T., \& Worthington, S. (Eds.). (2021). Citizen Science Skilling for Library Staff, Researchers, and the Public. In Citizen Science for Research Libraries. LIBER Citizen Science Working Group. https://cs4rl.github.io/guide/ Hayles, N. K. (2002). Writing machines. MIT Press.

Hobson, M., Tunstall, K. E., Warman, C., \& Duc, P. (2016). Denis Diderot 'Rameau's Nephew' - 'Le Neveu de Rameau': A Multi-Media Bilingual Edition (P. Duc, Trans.). Open Book Publishers. https://doi.org/10.11647/OBP.0098

Introducing Performing Archive: Edward S. Curtis + 'the vanishing race”. (2013, October 17). Alliance for Networking Visual Culture. https://scalar.me/anvc/performing- 
archive-edward-s-curtis-the-vanishing-race/

Introduction. (n.d.). In Performing Archive. Retrieved 27 January 2021, from https://scalar.usc.edu/works/performingarchive/intro

Jenkins, H., Shresthova, S., Gamber-Thompson, L., Kligler-Vilenchik, N., \& Zimmerman, A. (2016). By Any Media Necessary: The New Youth Activism. NYU Press. http://hdl.handle.net/2333.1/brv15jọp

Juhasz, A. (n.d.). Learning from YouTube. Alexandra Juhasz. Retrieved 27 January 2021, from http://alexandrajuhasz.com/books/learning-from-youtube/

Juhasz, A. (2011). Learning From YouTube. MIT Press.

http://vectors.usc.edu/projects/learningfromyoutube/

Kolb, D. (1994). Socrates in the labyrinth: Hypertext, Argument, Philosophy. Eastgate Systems. http://www.eastgate.com/catalog/Socrates.html

Kuc, K., \& Zylinska, J. (2016). Photomediations: A Reader. Open Humanites Press. http://www.openhumanitiespress.org/books/titles/photomediations/

Lessig, L. (2006). Code (Version 2.0). Basic Books.

https://web.archive.org/web/20190314234037/http://www.codev2.cc/

Lessig, L. (2019, March 15). About: Codev2.

https://web.archive.org/web/20190315013606/http://www.codev2.cc/about

LIBER Citizen Science Working Group (2021) Citizen Science Skilling for Library Staff, Researchers, and the Public. LIBER Citizen Science Working Group.

https://cs4rl.github.io/guide/\#

Liquid/Living Books. (n.d.). Open Humanities Press. Retrieved 27 January 2021, from http://www.openhumanitiespress.org/books/series/liquid-books/

Living Books About History. (n.d.). Retrieved 27 January 2021, from https://www.living $\underline{\text { booksabouthistory.ch/en/ }}$

Long, C. (2013, July 19). Performative Publication. Christopher P. Long. http://cplong.org/2013/07/performative-publication/

Long, C. P. (2017). Socratic and Platonic Political Philosophy: Practicing a Politics of Reading. Cambridge University Press. 
https://www.cambridge.org/gb/academic/subjects/politics-internationalrelations/political-theory/socratic-and-platonic-political-philosophy-practicing-politics$\underline{\text { reading? } \text { format }=A R \& i s b n=9781139899048}$

Marino, M. C. (2021). Aesthetic Programming teaches programming to critical coders. Cultural Studies, O(0), 1-3. https://doi.org/10.1080/09502386.2021.1993291

Marino, M. C., \& Ciston, S. (2021, August 19). How to Fork a Book: The Radical Transformation of Publishing. Medium. https://markcmarino.medium.com/how-to-forka-book-the-radical-transformation-of-publishing-3e1f4a39a66c

Mattering Press. (n.d.). Books. Retrieved 27 January 2021, from https://www.matteringpress.org/books

McLuhan, M., Fiore, Q., \& Agel, J. (1967). The Medium is The Massage. Gingko Press. http://archive.org/details/pdfy-vNiFct6b-L5ucJEa

Méndez Cota, G., Torres, L. E., Toxqui, M., \& Arziniaga, Á. (2016). En Busca del Quelite Perdido. Consejo Nacional para la Cultura y las Artes.

https://web.archive.org/web/20180807002404/http:/enbuscadelqueliteperdido.com/

Miller, Abbott, Fiore, Q., \& Friedman, D. (n.d.). Quentin Fiore: Massaging the message. Retrieved 27 January 2021, from http://www.eyemagazine.com/feature/article/quentinfiore-massaging-the-message

Miller, Allison. (2018, May 1). The Story of the Multigraph Collective / Perspectives on History / AHA. https://www.historians.org/publications-and-directories/perspectives-onhistory/may-2018/the-story-of-the-multigraph-collective

Miller, P. D., COMA, \& Hally, P. (2004). Rhythm Science (1st ed.). The MIT Press. https://mitpress.mit.edu/sites/default/files/titles/content/mediawork/titles/rhythm/rhyth m book.html

Nordhoff, S. (2017, June 27). Document lifecycles and fluid publication / Language Science Press Blog. https://userblogs.fu-berlin.de/langsci-press/2017/06/27/documentlifecycles-and-fluid-publication/

Nordhoff, S. (2020, September 14). Collecting reader feedback with PaperHive, docLoop and GitHub / Language Science Press Blog. https://userblogs.fuberlin.de/langsci-press/2020/09/14/collecting-reader-feeback-with-paperhive-docloopand-github/ 
NYU Press. (n.d.-a). About Open Square. Open Square: NYU Press. Retrieved 27 January 2021, from http://opensquare.nyupress.org/aboutopensquare/

NYU Press. (n.d.-b). Connected Youth and Digital Futures. Retrieved 27 January 2021, from http://connectedyouth.nyupress.org/index.html

OBP Customise. (n.d.). Open Book Publishers. Retrieved 11 December 2020, from https://www.openbookpublishers.com/section/59/1

Open Humanities Press. (n.d.). Living Books About Life. Retrieved 10 December 2020, from http://www.living $\underline{\text { booksaboutlife.org } /}$

Paim, J. S. (2015). O que é o SUS: E-book interativo. Editora Fiocruz. https://doi.org/10.7476/9788575413425

Paul, E., McKenzie, D., Raibmon, P., \& Johnson, H. (2019). As I Remember It: Teachings (Pəms taPaw) from the Life of a Sliammon Elder. UBC Press.

https://doi.org/10.14288/SNS9-9159

Pressman, J. (n.d.). Technotexuality: An Interview with N. Katherine Hayles and Anne Burdick, author and designer of Writing Machines. Writing Machines - Web Supplement: User's Guide. Retrieved 27 January 2021, from https://mitpress.mit.edu/sites/default/files/titles/content/mediawork/titles/writing/writin g_book_inter.html

Rayner, S. J. (2017). Introduction: Academic Book of the Future BOOC. In BOOC. UCL Press. https://doi.org/10.14324/111.9781911307679.00

Schäfer, R. (2018). Einführung in die grammatische Beschreibung des Deutschen: Dritte, überarbeitete und erweiterte Auflage. Language Science Press. https://langscipress.org/catalog/book/224

Soon, W. (2017). Executing Liveness-Research-Aarhus University.

https://pure.au.dk/portal/en/publications/executing-liveness (8d9b9851-31fc-4e6b-b0e2dfe710e6c96e).html

The Multigraph Collective. (2018). Interacting with Print: Elements of Reading in the Era of Print Saturation. University of Chicago Press. https://doi.org/10.7208/chicago/9780226469287.001.0001 
The Turing Way Community, Becky Arnold, Louise Bowler, Sarah Gibson, Patricia Herterich, Rosie Higman, Anna Krystalli, Alexander Morley, Martin O’Reilly, \& Kirstie Whitaker. (2019). The Turing Way: A Handbook for Reproducible Data Science. Zenodo. https://doi.org/10.5281/zenodo.3233986

Trettien, W. (n.d.). Cut/Copy/Paste. Fragments of History. University Of Minnesota Press. https://manifold.umn.edu/projects/cut-copy_paste

Tsing, A.L., Deger, J., Keleman Saxena, A., and Zhou, F. (eds.) (2021) Feral Atlas: The More-Than-Human Anthropocene. Stanford University Press. http://feralatlas.org

UCLPress. (n.d.). BOOC (Academic Book of the Future). Retrieved 10 December 2020, from https://ucldigitalpress.co.uk/BOOC

uncertain commons. (2013). Speculate This! Duke University Press. https://speculatethis.pressbooks.com/

University of Chicago Press. (n.d.). The Multigraph Collective. Retrieved 27 January 2021, from https://press.uchicago.edu/ucp/books/author/T/Other/au26755322.html

Wark, M. (2007a). Gamer theory. Harvard University Press. http://futureofthebook.org/mckenziewark/index.html

Wark, M. (2007b, April 22). Gamer Theory 3.0 (Visualizations). Gamer Theory. http://futureofthebook.org/mckenziewark/visualizations/index.html

Wernimont, J., Kim, D. J., Schonberg, S., Borsuk, A., Schuster, B., Blackmore, H., \& Gosart (Popova), U. (2018). Performing Archive: Curtis + "the vanishing race". Scalar. https://scalar.usc.edu/works/performingarchive/index

Yates-Doerr, E., \& Labuski, C. (2017). The Ethnographic Case. Mattering Press. https://doi.org/10.28938/995527744

Young, D. (2021). Theorising while() Practising: A Review of Aesthetic Programming. Computational Culture, 8. http://computationalculture.net/theorising-while-practising-areview-of-aesthetic-programming $/$

Zylinska, J. (2015, February 22). Photomediations: An Introduction. Liquidbooks. http://liquidbooks.pbworks.com/w/page/93066645/Photomediations\%3A\%20An\%20Intr oduction 
Zylinska, J., Kuc, K., Shaw, J., Varney, R., \& Wamposzyc, M. (2015). Photomediations: An Open Book. http://photomediationsopenbook.net/

\section{External resource}

The bibliographies for all parts of this report are openly available on Zotero.

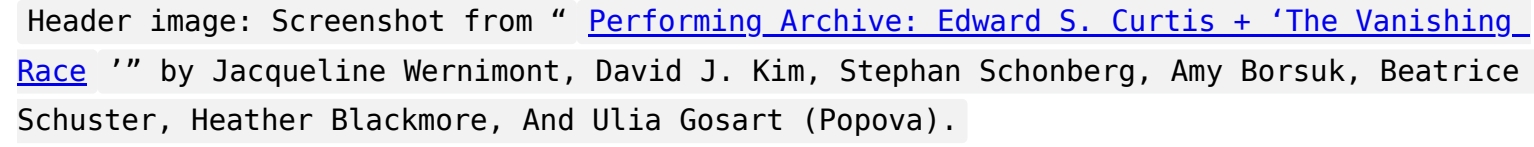

\section{Footnotes}

1. For an updated and more detailed discussion of Computational Book Publishing, see the Computational Book Publishing section that is part of the 3rd part of this report on Technical Workflows. $\doteq$

\section{Citations}

1. Young, D. (2021). Theorising while Practising: A Review of Aesthetic

Programming. Computational Culture, 8. http://computationalculture.net/theorisingwhile-practising-a-review-of-aesthetic-programming $L \boxminus$

2. Marino, M. C. (2021). Aesthetic Programming teaches programming to critical coders. Cultural Studies, 1-3. https://doi.org/10.1080/09502386.2021.1993291 3. Marino, M. C., \& Ciston, S. (2021). How to Fork a Book: The Radical Transformation of Publishing. In Medium. https://markcmarino.medium.com/how-tofork-a-book-the-radical-transformation-of-publishing-3e1f4a39a66c $\subseteq$ 4. The Turing Way Community and Becky Arnold and Louise Bowler and Sarah Gibson and Patricia Herterich and Rosie Higman and Anna Krystalli and Alexander Morley and Martin O’Reilly and Kirstie Whitaker. (2019). The Turing Way: A Handbook for Reproducible Data Science. Zenodo.

https://doi.org/10.5281/zenodo.3233986

5. Hobson, M., Tunstall, K. E., Warman, C., \& Duc, P. (2016). Denis Diderot "Rameau's Nephew" - "Le Neveu de Rameau": A Multi-Media Bilingual Edition. 
Open Book Publishers. https://doi.org/10.11647/OBP.0098

6. Paim, J. S. (2015). O que é o SUS: E-book interativo. Editora Fiocruz. http://www.livrosinterativoseditora.fiocruz.br/sus/ $\subseteq$

7. Babini, D., \& Rovelli, L. (2020). Tendencias recientes en las políticas científicas de ciencia abierta y acceso abierto en Iberoamérica. CLACSO : Fundación Carolina. $\triangleq$ 8. NYU Press. (n.d.). About Open Square. In Open Square: NYU Press. http://opensquare.nyupress.org/aboutopensquare/ $\triangleq$ 9. NYU Press. (n.d.). Connected Youth and Digital Futures. http://connectedyouth.nyupress.org/index.html $\triangleq$ 10. Ganahl, S. (2022). Campus Medius: Digital Mapping in Cultural and Media Studies. https://www.degruyter.com/isbn/9783839456019 11. Phone \& Spear: A Yuta Anthropology. (2019). Goldsmiths press. $\bullet$ 12. Boluk, S., \& LeMieux, P. (2017). Metagaming: Playing, Competing, Spectating, Cheating, Trading, Making, and Breaking Videogames (Issue 53). University of Minnesota Press. https://www.upress.umn.edu/book-division/books/metagaming $\triangleq$ 13. uncertain commons. (2013). Speculate This! Duke University Press. https://speculatethis.pressbooks.com/

14. University of Chicago Press. (2017). The Multigraph Collective. https://press.uchicago.edu/ucp/books/author/T/Other/au26755322.html $\triangleq$ 15. Miller, A. (2018). The Story of the Multigraph Collective Itextbar Perspectives on History Itextbar AHA. https://www.historians.org/publications-anddirectories/perspectives-on-history/may-2018/the-story-of-the-multigraph-collective $\triangleq$ 16. Anon Collective. (2021). Book of Anonymity. punctum books.

https://doi.org/10.21983/P3.0315.1.00

17. Pressman, J. (2002). Technotexuality: An Interview with N. Katherine Hayles and Anne Burdick, author and designer of Writing Machines. In Writing Machines - Web Supplement: User's Guide.

https://mitpress.mit.edu/sites/default/files/titles/content/mediawork/titles/writing/writ $\underline{\text { ing_book inter.html }} \leftrightharpoons$ 
18. Miller, P. D., COMA, \& Hally, P. (2004). Rhythm Science (1st ed.). The MIT Press. https://mitpress.mit.edu/sites/default/files/titles/content/mediawork/titles/rhythm/rhyt $\underline{\mathrm{hm} \text { book.html }} \leftrightharpoons$

19. Miller, A., Fiore, Q., \& Friedman, D. (1993). Quentin Fiore: Massaging the message. http://www.eyemagazine.com/feature/article/quentin-fiore-massaging-the-



20. Tsing, A. L., Deger, J., Saxena, A. K., \& Zhou, F. (2020). Feral Atlas: The MoreThan-Human Anthropocene. Stanford University Press.

https://doi.org/10.21627/2020fa $ヒ$ 21. commentpress. (2009). In Planned Obsolescence. https://mcpress.mediacommons.org/plannedobsolescence/three-texts/commentpress/ 22. Yates-Doerr, E., \& Labuski, C. (2017). The Ethnographic Case. Mattering Press. https://doi.org/10.28938/995527744 $ヒ$ 23. Nordhoff, S. (2017). Document lifecycles and fluid publication Itextbar Language Science Press Blog. https://userblogs.fu-berlin.de/langscipress/2017/06/27/document-lifecycles-and-fluid-publication/ $\triangleq$ 24. Nordhoff, S. (2020). Collecting reader feedback with PaperHive, docLoop and GitHub Itextbar Language Science Press Blog. https://userblogs.fu-berlin.de/langscipress/2020/09/14/collecting-reader-feeback-with-paperhive-docloop-and-github/ 25. Introducing Performing Archive: Edward S. Curtis + 'the vanishing race”. (2013). In Alliance for Networking Visual Culture. https://scalar.me/anvc/performing-archiveedward-s-curtis-the-vanishing-race/ $\leftrightarrows$

26. Introduction. (n.d.). In Performing Archive.

https://scalar.usc.edu/works/performingarchive/intro 27. Zylinska, J. (2015). Photomediations: An Introduction. In liquidbooks.

http://liquidbooks.pbworks.com/w/page/93066645/Photomediations\%3A\%20An\%20In $\underline{\text { troduction }} \leftrightharpoons$

28. A Guide To Open And Hybrid Publishing. (2014). https://www.europeanaspace.eu/wp-content/uploads/2014/04/Guide to_Open and_Hybrid_Publishing.pdf 29. Kuc, K., \& Zylinska, J. (2016). Photomediations: A Reader. Open Humanites Press. http://www.openhumanitiespress.org/books/titles/photomediations/ $\triangleq$ 
30. Bauch, N. (2016). Enchanting the Desert: A Pattern Language for the Production of Space. http://www.enchantingthedesert.com/home/ $\uplus$

31. Kolb, D. (1994). Socrates in the labyrinth: Hypertext, Argument, Philosophy.

Eastgate Systems. http://www.eastgate.com/catalog/Socrates.html $ヒ$ 32. Greco, D. (1995). Cyborg: engineering the body electric. Eastgate Systems. http://www.eastgate.com/catalog/Cyborg.html $\triangleq$ 33. Paul, E., McKenzie, D., Raibmon, P., \& Johnson, H. (2019). As I Remember It: Teachings (P|Elzschwams taPaw) from the Life of a Sliammon Elder. http://publications.ravenspacepublishing.org/as-i-remember-it/about $\triangleq$ 34. Liquid/Living Books. (n.d.). In Open Humanities Press. http://www.openhumanitiespress.org/books/series/liquid-books/ 35. Méndez Cota, G., Torres, L. E., Toxqui, M., \& Arziniaga, Á. (2016). En Busca del Quelite Perdido. Consejo Nacional para la Cultura y las Artes. https://web.archive.org/web/20180807002404/http:/enbuscadelqueliteperdido.com/ $\triangleq$ 36. About: Living Books About History. (n.d.). https://www.livingbooksabouthistory.ch/en/about $\triangleq$ 37. Rayner, S. J. (2017). Introduction: Academic Book of the Future BOOC. In BOOC. UCL Press. https://doi.org/10.14324/111.9781911307679.00 38. Long, C. (2013). Performative Publication. In Christopher P. Long. http://cplong.org/2013/07/performative-publication/ 39. Juhasz, A. (2011). Learning from YouTube. http://alexandrajuhasz.com/books/learning-from-youtube/ 40. Long, C. P. (2013). Performative Publication. http://cplong.org/2013/07/performative-publication/ 41. Grigar, D., Schiller, N., Rhodes, V., Gwin, M., Whitney, V., \& Bowen, K. (2018). Rebooting Electronic Literature: Photos of David Kolb's "Socrates in the Labyrinth." In Rebooting Electronic Literature: Documenting Pre-Web Born Digital Media (Vol. 1). Electronic Literature Lab. $\subseteq$ 42. Amerika, M. (2011). Remixthebook. U of Minnesota Press. http://www.remixthebook.com/ $\leftrightharpoons$ 
43. OBP Customise. (n.d.). In Open Book Publishers. https://www.openbookpublishers.com/section/59/1

44. Wark, M. (2007). Gamer Theory 3.0 (Visualizations). In Gamer Theory. http://futureofthebook.org/mckenziewark/visualizations/index.html

45. Trettien, W. (n.d.). Cut/Copy/Paste. Fragments of History. University Of Minnesota Press. https://manifold.umn.edu/projects/cut-copy=paste 46. dos Anjos, A. (2020). Rede CoVida lança primeiro e-book com conhecimentos sobre a pandemia da Covid-19. In Rede Covida - Ciência, Informação e Solidariedade. https://redecovida.org/2020/12/15/rede-covida-lanca-primeiro-e-bookcom-conhecimentos-sobre-a-pandemia-da-covid-19-em-evento-online/ $\triangleq$

47. Lessig, L. (2019). About: Codev2.

https://web.archive.org/web/20190315013606/http://www.codev2.cc/about

48. Nordhoff, S. (2020). Collecting reader feedback with PaperHive, docLoop and GitHub Itextbar Language Science Press Blog. https://userblogs.fu-berlin.de/langscipress/2020/09/14/collecting-reader-feeback-with-paperhive-docloop-and-github/

49. Hansen, J. S., Kaarsted, T., \& Worthington, S. (Eds.). (2021). Citizen Science Skilling for Library Staff, Researchers, and the Public. In Citizen Science for Research Libraries. LIBER Citizen Science Working Group. https://cs4rl.github.io/guide/ $\underline{\underline{ }}$ 